\title{
“A BANCA É O MEU PALCO!”: JOGADORES E DEALERS NUM CASINO EM PORTUGAL
}

\section{“THE TABLE IS MY STAGE”: PLAYERS AND DEALERS IN A PORTUGUESE CASINO}

\author{
João Gomes \\ joao.nicolau.gomes@gmail.com
}

Doutorando em Antropologia Social e Cultural no Programa de Doutoramento do Instituto Superior de Ciências Sociais e Políticas, Instituto de Ciências Sociais da Universidade de Lisboa e bolsista de pesquisa da Fundação para a Ciência e Tecnologia (FCT).

ORCID: https://orcid.org/0000-0002-3954-1977

\section{RESUMO}

Nos casinos, tal como acontece na grande generalidade do sector dos serviços, produção e consumo decorrem em simultâneo e no mesmo espaço. O processo de trabalho deriva, como tal, do encontro de subjectividades entre trabalhadores e clientes. Este artigo, baseado numa investigação etnográfica, procura analisar o processo laboral dos pagadores de banca (dealers/croupiers) num dos principais casinos portugueses, particularmente, as dinâmicas relacionais e interactivas entres estes profissionais e os jogadores. Os pagadores de banca, apesar de estrutural e hierarquicamente subordinados, são agentes activos nestas micro-interacções. Desta forma, rejeitam a subordinação interactiva que, normalmente, acompanha a estrutural, empregando um conjunto de estratégias performativas que visam inverter, simbólica e temporariamente, as hierarquias sociais. Gerindo, selectivamente, as suas ofertas estéticas e emocionais, os pagadores de banca constituem-se como agentes não subordinados, controladores, autoritários e superiores. No entanto, ao criar a dignidade na subordinação, estas estratégias tendem a produzir "consentimento" e não emancipação.

Palavras-chave: casinos; trabalho; pagadores de banca; jogadores.

\section{ABSTRACT}

In casinos, like in the majority of the service economy, production and consumption take place simultaneously and in the same space. As such, the labor process derives from the encounter of workers and customers subjectivities. This article, based on an ethnographic research, seeks to analyze the labor process of dealers in a Portuguese casino, particularly, the interactive dynamics between workers and customers. Dealers, although structurally and hierarchically subordinated, are active agents in these micro-interactions. In this way, they reject the interactive subordination that normally accompanies the structural, employing a set of performative strategies that, symbolically and temporarily, subvert the social hierarchies. Selectively managing their aesthetical and emotional labor, dealers constitute themselves as non-subordinate agents. However, by creating dignity in subordination, these strategies tend to produce "consent" not emancipation.

Keywords: casinos; work; dealers; players. 


\section{INTRODUÇÃO}

Durante longas décadas, os casinos portugueses permaneceram universos sociais e laborais hermeticamente fechados. A indústria do jogo, regulamentada pela primeira vez, em 1927 (PORTUGAL, 1927), foi um alvo sistemático das preocupações moralistas do regime (VAQUINHAS, 2006; CRESPO, 2012). Neste sentido, o Estado decidiu isolar o jogo em "guetos de riqueza" (LEFEBVRE, 2011, p. 98) e condicionar o acesso aos casinos. A revisão da lei de jogo, elaborada pelo Estado Novo em 1958, proibia as "mulheres casadas" e os "assalariados" de frequentarem os casinos (PORTUGAL, 1958). Mimetizando o exclusivismo da indústria do jogo e manipulando os instrumentos corporativos do regime, os trabalhadores dos casinos implementaram, sistematicamente, políticas sindicais de closed shop que visavam restringir o acesso à categoria profissional de pagador de banca (dealer/croupier) (GOMES, no prelo).

Desta forma, este é o primeiro artigo que procura analisar, etnograficamente, o processo laboral nos casinos em Portugal ${ }^{1}$. Entre Junho e Outubro de 2017, utilizando a técnica da observação participante, trabalhei como contínuo (ou auxiliar de banca) num dos principais casinos portugueses. Posteriormente, realizei 46 entrevistas a 40 profissionais de dois casinos pertencentes à mesma empresa concessionária ${ }^{2}$. Por fim, entre Outubro de 2018 e Março de 2019, frequentei o curso de pagador de banca.

Habitualmente, os casinos são conceptualizados como "meios de consumo" (RITZER, 2005). O vasto e complexo universo laboral que suporta estas actividades raramente emerge como potencial campo de investigação (SALLAZ, 2009). No entanto, o processo laboral nos casinos, como na grande generalidade do sector dos serviços, deriva do encontro de subjectividades entre trabalhadores e clientes (SHERMAN, 2007). Produção e consumo decorrem em simultâneo e no mesmo espaço físico, dificultando a sua rígida separação conceptual, ou seja, o trabalhador consome a experiência de jogo que produz e o cliente produz a experiência de jogo que consome (SHERMAN, 2007; MATOS, 2015; KEAT; WHITELEY; ABERCROMBIE, 1994; CASACA, 2012; MACDONALD; KORCZYNSKI, 2009). A "nova morfologia do trabalho" (ANTUNES, 2013), na era da "acumulação flexível” (HARVEY, 1989), é constituída por um "proletariado emocional" (MACDONALD; MERRILL, 2009) e estruturada por um "mercado da personalidade" (MILLS, 1951). As empresas, procurando assegurar vantagens competitivas no mercado, atribuem uma importância crescente à "relação de serviço" entre trabalhador e cliente (CASACA, 2012). Como tal, em detrimento das competências técnicas (ou hard skills), começaram a ganhar relevância elementos como a sociabilidade, o relacionamento interpessoal, a amabilidade, a simpatia, a boa apresentação e a deferência, ou seja, as competências sociais (ou soft skills) (CASACA, 2012; HOCHSCHILD, 2003; MACDONALD; SIRIANNI, 1996; MACDONALD; KORCZYNS- 
KI, 2009; MATOS, 2015; WOLKOWITZ, 2006). Mas não se exige, sempre e em todas as circunstâncias, as mesmas competências (SHERMAN, 2007; SALLAZ, 2009). Assim, os casinos são "regimes de produção de serviços” (SALLAZ, 2009), histórica e socialmente, específicos.

Assim, este artigo procura analisar o processo laboral dos pagadores de banca num dos principais casinos portugueses, em particular, as relações e interacções entre estes profissionais e os jogadores. Apesar de estrutural e hierarquicamente subordinados, estes "trabalhadores interactivos" representam, interpretam, agenciam e manipulam o seu contexto de subordinação (SHERMAN, 2007; SALLAZ, 2009; LEIDNER, 1993; PAULES, 1991). Eles são uma "força activa" que rejeita esse estatuto subordinado (PAULES, 1991), impondo as suas próprias "hierarquias simbólicas alternativas” (LAMONT, 2000; SHERMAN, 2007) e as suas escalas de valor próprias. Nas micro-interacções quotidianas com os clientes, os pagadores invertem, temporária e simbolicamente, as hierarquias sociais, empregando um conjunto de estratégias performativas que tendem a desmentir a subordinação interactiva, normalmente decorrente da subordinação estrutural (SHERMAN, 2007; PAULES, 1991). Instrumentalizando o seu processo laboral e os recursos por ele providenciados (SHERMAN, 2007), os pagadores de banca gerem, selectivamente, o seu "trabalho estético e emocional" (CASACA, 2012; HOCHSCHILD, 2003; MACDONALD; SIRIANNI, 1996; MACDONALD; KORCZYNSKI, 2009; WOLKOWITZ, 2006), isto é, distribuem, estratégica e discricionariamente, as suas ofertas estéticas e emocionais aos jogadores (SALLAZ, 2009). O serviço prestado pelos pagadores numa banca de jogo depende, portanto, do fenómeno que Robin Leidner (1993) denominou por "alianças de interesses tripartidas" (three-way interest alliance), ou seja, os trabalhadores dos serviços tendem a aliar-se, temporária e circunstancialmente, aos clientes ou à empresa, consoante a estratégia que lhes for mais benéfica no momento. Neste processo, os pagadores apropriam-se dos recursos que o contexto jurídico, organizacional e profissional coloca à sua disposição para se constituírem como "agentes não subordinados", controladores, autoritários e superiores (SHERMAN, 2007; LAMONT, 2000). Tal significa que os pagadores de banca, enquadrados pela apertada regulamentação do Estado e pelas "estratégias de controlo" (FRIEDMAN, 1977) organizacionais, manipulam e instrumentalizam os recursos que são colocados à sua disposição (SHERMAN, 2007). Em primeiro lugar, a apertada regulamentação do jogo permite-lhes, em determinados casos, refugiarem-se nos seus procedimentos de trabalho, desresponsabilizando-se pelas ocorrências na banca. Em segundo lugar, os casinos em Portugal nunca conseguiram controlar, na plenitude, a sua força de trabalho, porque o mercado laboral, que historicamente era controlado pelo sindicato corporativo e protegido pelo Estado, permaneceu reduzido e dependente de skills raras (GOMES, no prelo), favorecendo, desta forma, a implementação 
de "estratégias de controlo" "hegemónicas" (BURAWOY, 1985), que garantem uma significativa autonomia dos pagadores nas suas bancas de jogo (SALLAZ, 2009). Por fim, o contexto profissional, altamente masculinizado e elitista, assente em características como a seriedade, formalidade e elegância do serviço prestado, também providencia importantes recursos aos pagadores de banca, permitindo-lhes preservar a sua autoridade, controlo e independência no processo laboral. Desta forma, é inevitável estabelecer a associação entre o serviço prestado pelos pagadores de banca no contexto concreto e interactivo dos casinos e as estruturas sociais que regulam a sua actividade (SALLAZ, 2009). No entanto, apesar de se constituírem como agentes activos no seu processo laboral, através da instrumentalização dos recursos providenciados pelo mesmo contexto que os subordina, os pagadores de banca, ao criarem a dignidade na subordinação, "normalizam" e "consentem" as relações de dominação e exploração que sobre eles incidem (SHERMAN, 2007).

\section{A RETIRADA E A HIPERBOLIZAÇÃO DA AGÊNCIA}

A presença do consumidor no processo de trabalho alterou, significativamente, o paradigma tradicional das relações laborais (SHERMAN, 2007). Transformado numa instância de controlo adicional, o cliente, efectivamente, implica uma dupla subordinação do trabalhador (SHERMAN, 2007; LEIDNER, 1993; SALLAZ, 2009; CASACA, 2012; MACDONALD; KORCZYNSKI, 2009). Esta é a perspectiva adoptada por H. Lee Barnes (2002, p. 4) na sua análise sobre a cultura de trabalho dos dealers em Las Vegas: "apanhados entre a esperança dos jogadores e a vantagem da casa está o dealer" . Opinião partilhada por Erwin Goffman (2011, p. 174):

[Os] carteadores de cassinos de Nevada podem começar os seus turnos sabendo que são eles que precisam encarar as intenções duras dos jogadores de ganhar, e ficar friamente no caminho deles bloqueando consistentemente a habilidade, a sorte e as trapaças para não perderem a reputação precária que têm com os gerentes.

No entanto, Leidner (1993) assinala que a presença do cliente, mediando as relações entre trabalhadores e gestores, permite o estabelecimento de alianças temporárias que dinamizam as relações laborais. Em claro contraste com H. Lee Barnes (2002) e Erwin Goffman (2011), esta é a perspectiva adoptada por Jeffrey Sallaz (2009), na sua investigação etnográfica sobre os dealers em Las Vegas e Joanesburgo:

Os dealers não são mediadores passivos entre os jogadores e a casa. Pelo contrário, eles desempenham um papel activo na determinação dos resultados do jogo e na estruturação da experiência do jogo. [...] Os dealers agem de acordo com o seu próprio interesse, não se identificando sistematicamente com a casa ou com os jogadores [...], por vezes aliam-se ao casino para levar à falência um jogador que não gratifica; 
por outras, aliam-se a um jogador que gratifica desejando que este ganhe (SALLAZ, 2009, p. 4 e 61).

Estas observações não passam despercebidas aos próprios pagadores de banca dos casinos analisados. Em contexto de entrevista, Maria, pagadora de banca com cerca de 15 anos de experiência profissional, assinala: "nós estamos numa posição muito ingrata, porque nós, enquanto trabalhadores da empresa, queremos que eles percam, mas enquanto pessoas que ganham gratificações [gorjetas], queremos que eles ganhem. [...] Temos sempre que jogar com isto".

Os pagadores de banca, como outras categorias profissionais de outros sectores de actividade, gerem, minuciosa e contextualmente, as suas alianças com os clientes ou com a empresa de acordo com os seus interesses momentâneos (SALLAZ, 2009; LEIDNER, 1993; SHERMAN, 2007; CASACA, 2012). Ao confrontarem clientes que evidenciam o carácter subordinante da "relação de serviço", os pagadores aliam-se à empresa, refugiando-se nos seus procedimentos de trabalho e nos automatismos adquiridos no decorrer da sua experiência laboral. Desta forma, protegem-se do erro, ao utilizarem os procedimentos de trabalho como "escudos de protecção" (RAFAELI; SUTTON, 1987) que os desresponsabilizam pelas ocorrências do jogo, e protegem-se do jogador, pelo distanciamento emocional criado e preservado. Por outro lado, os pagadores de banca aliam-se aos jogadores contra a casa quando estas relações lhes asseguram benefícios materiais e simbólicos, como gratificações ou status. Nestes casos, os trabalhadores contornam os procedimentos internos da empresa e a própria regulamentação do Estado, procurando envolver-se, emocionalmente, no jogo. Estas duas alianças circunstanciais correspondem a duas estratégias performativas: a retirada de agência e a hiperbolização da agência. A primeira não equivale à ausência de agência, porque, tal como a segunda, é uma estratégia performativa, ou seja, ela é deliberadamente operacionalizada pelos pagadores de banca. Eles agenciam, ou performatizam, a sua ausência de agência quando se aliam à casa, remetendo-se ao cumprimento rigoroso dos procedimentos de trabalho, ao respeito minucioso da lei de jogo e à execução mecânica das suas rotinas laborais. Neste processo, desresponsabilizam-se pelos resultados do jogo, evitam o seu envolvimento emocional e preservam a distância em relação aos jogadores. As camadas de gestão nos casinos analisados, tal como observara Sallaz (2009) em relação aos casinos de Las Vegas, tendem a activar, selectivamente, o "panóptico" (FOUCAULT, 1999) organizacional. Ou seja, os pagadores, possuindo, na maior parte das circunstâncias, autonomia no seu processo laboral, são alvos de apertada vigilância e controlo quando, ocasionalmente, elevados valores circulam nas bancas, quando os jogadores se apresentam particularmente irascíveis, ou quando o volume de jogo se intensifica. Nestes casos, a autonomia dos pagadores de banca é, efectivamente, reduzida. No entanto, eles não se remetem à condição 
de autómatos. Manter a distância, a formalidade e a impessoalidade no trato, reduzir os diálogos e os contactos visuais com os jogadores, conservar uma expressão facial imperturbável permite, aos pagadores, não apenas reduzir as possibilidades de erro, pelo afunilamento do seu foco sobre o pano de jogo, mas, igualmente, disciplinar os comportamentos dos jogadores. Como assinala Sallaz (2009, p. 56 e 72):

Nestas situações, é tentador negar a agência, porque os jogadores podem tornar-se frustrados e abusivos, gritando e chamando todos os nomes ao dealer [...]. Eles procuram obscurecer o seu próprio poder nas mesas, para se desembaraçarem da suspeição por parte dos gestores e da raiva por parte dos jogadores.

Esta postura, assumida pelos pagadores, facilita a transmissão de uma mensagem de segurança, confiança, profissionalismo e autoridade sobre as bancas de jogo e, pela impessoalidade e formalidade no trato, disciplina os jogadores, não dando azo ao pleno desenvolvimento das suas emoções, alegrias e frustrações.

Mas a retirada de agência apresenta ainda uma importante variante, correspondente ao que os dealers norte-americanos designam por “dummy up and deal" (SALLAZ, 2009; BARNES, 2002; SOLKEY, 1980). A preponderância desta performance estética e emocional no universo social e laboral dos casinos não deve ser negligenciada. Lee Solkey (1980), tendo trabalhado como dealer na década de 1970 em Las Vegas, assinala que os trabalhadores eram incentivados a não demonstrar qualquer tipo de emoção nas bancas. O seu relato é elucidativo:

Estava um homem sentado na base central da banca que se agarrou ao peito, gemeu, empalideceu, cambaleou e tombou para o chão. Eu saltei, sem saber o que fazer e o chefe de sala gritou-me: «continua a pagar». [...] O homem estava morto, claro, mas eu nunca perdi o ritmo. Continuei a pagar (SOLKEY, 1980, p. 60).

No entanto, esta performance estética e emocional é reservada para as ocasiões excepcionais em que o jogador faz uso da sua "autoridade de reserva" (SHERMAN, 2007), ou quando o grau de "panóptico" a que o trabalhador está sujeito se intensifica, isto é, quando, circunstancialmente, a "estratégia de controlo" transita para o "despotismo" (BURAWOY, 1985). Esta estratégia mantém as características enunciadas anteriormente, mas com uma diferença fundamental: a retirada de agência, neste caso, não é apenas uma performance instrumentalizada pelo pagador com o objectivo de preservar a sua autoridade sobre a banca de jogo, é, única e exclusivamente, um mecanismo de defesa. Não é uma estratégia instrumental, mas necessária. Não salvaguarda a autoridade do pagador sobre a banca, ao invés, é operacionalizada apenas quando o pagador já perdeu essa autoridade. Como a retirada de agência, neste exemplo, não é contrabalançada pela manutenção de autoridade, o pagador transforma-se, efectivamente, num agente subordinado. No entanto, o pagador 
conserva ainda um recurso fundamental: o controlo do ritmo de jogo. Mesmo neste caso extremo de restrição e coacção, o pagador não se encontra, totalmente, destituído de agência. Aliando-se à casa, o pagador joga com as probabilidades que a beneficiam. Aumentando o ritmo de jogo, o pagador executa mais golpes. Se, num golpe, as probabilidades encontram-se já a favor da casa, num maior número de golpes, maiores são as probabilidades de derrota do jogador. Assim, ao acelerar o ritmo de jogo, o pagador procura expulsar o jogador da banca, antecipando a sua derrota e levando-o à falência (SALLAZ, 2009). Estas duas variantes da retirada de agência ocupam uma posição privilegiada nos discursos dos pagadores de banca entrevistados. Segundo os seus testemunhos, a imprevisibilidade do público nos casinos é reforçada pelo ambiente de tensão, pelo carácter potencialmente aditivo do jogo, pelas variações súbitas de humor, pelos elevados valores em circulação e pelo consumo de álcool. Por estes motivos, o seu atendimento deve ser impessoal, distante e formal, diferente, portanto, do tipo de atendimento assente no relacionamento interpessoal, sociabilidade, amabilidade e deferência. De facto, esta também havia sido a minha percepção inicial. No entanto, no decorrer do meu trabalho de campo, observei como a importância desta postura havia sido largamente exagerada. Aliás, alguns entrevistados admitem que o seu serviço é, fundamentalmente, circunstancial, isto é, depende da gestão minuciosa e momentânea das suas ofertas estéticas e emocionais. Atentemos em alguns destes relatos:

Devemos gerir o sorriso, porque sorrir para um jogador que está a perder pode ser considerado uma provocação. [...] Não podemos conversar com os clientes, porque depois existem abusos de confiança, nós não somos amigos deles (José, pagador de banca, 13 anos de experiência profissional).

Não olhar directamente para os jogadores, eles podem levar a mal. [...] Temos que ser inertes, amorfos e o mais diplomáticos possíveis. [...] Não nos podemos soltar muito, temos que fazer uma gestão muito dúbia. [...] Não há um limite objectivo, a gente é que tem que sentir a pessoa, se podemos conversar ou não, se podemos sorrir ou não (Raquel, pagadora de banca, sete anos de experiência profissional).

Nós sabemos que quando há um cliente que está muito contente, há outro que está muito triste, temos que gerir da melhor maneira sem mostrar preferências. [...] Há aqui colegas que estão sempre na conversa e depois, por isso, o jogo corre mal, porque se esquecem dos procedimentos, ou porque tiram cartas que não deviam, pronto, não estão com atenção (Susana, pagadora de banca, 16 anos de experiência profissional).

A melhor forma de abordar o cliente é deixá-lo falar e depois respondo, mas não sustento a conversa. [...] A relação depende do momento do cliente, se ele está a ganhar, se está a perder, se está bem-disposto, se não 
está bem-disposto [...]. O funcionário tem que gerir esses momentos. [...] A relação entre trabalhador e cliente não se pode estender muito, são coisas muito pontuais (Belchior, fiscal de banca4, 42 anos de experiência profissional).

Tento não me aproximar muito e não dar muita confiança. [...] Temos que estar sisudos, mas depende sempre dos jogadores (Rui, pagador de banca, 15 anos de experiência profissional).

Tanto estou a falar com alguém do bairro numa mesa, como ao lado estou a falar inglês ou italiano e tenho que tratar as pessoas de forma diferente. Tu com pessoas diferentes, lidas de formas diferentes, nem sempre esse balanço é fácil de se fazer, tem que se tentar encontrar ali o meio-termo. [...] Nós conseguimos estar a divertir-nos em determinadas bancas, conseguimos ser mesmo entertainers, mas também há mesas em que estamos de cara fechada (Hugo, pagador de banca, 14 anos de experiência profissional).

A melhor forma de resolver os conflitos é o silêncio, porque de outra forma podemos estar a mandar achas para a fogueira [...]. Claro que não é um silêncio com um sorriso palerma nos dentes, não digo que seja como um velório, mas é comungar um bocado da alegria ou dor do cliente (Alexandre, fiscal de banca, 35 anos de experiência profissional).

Portanto, os trabalhadores devem gerir, cuidadosamente, as suas ofertas estéticas e emocionais. Mas, quando a situação imediata permite atenuar ou subverter a retirada de agência, como se caracteriza o serviço destes profissionais? Nestes contextos, os pagadores tendem a mobilizar a segunda estratégia performativa: a hiperbolização da agência. Esta caracteriza-se pela aliança entre pagadores e jogadores contra o seu inimigo comum: a casa. A cooptação dos clientes permite, aos pagadores, ampliar o seu estatuto profissional, o valor das suas gorjetas e atenuar a monotonia e repetitividade do seu trabalho. Neste contexto, os pagadores investem-se emocionalmente no jogo, distribuem conselhos de estratégia pelos jogadores e reivindicam o "crédito" pelos resultados do jogo (SALLAZ, 2009). As regras dos jogos, os procedimentos de trabalho e a própria lei de jogo são, constantemente, contornados. A performance da hiperbolização da agência depende, em grande medida, da preservação de uma significativa autonomia nas bancas de jogo e, como tal, de uma "estratégia de controlo" "hegemónica" (BURAWOY, 1985) e da inactividade, ou, pelo menos, da mitigada actividade, do aparelho "panóptico". O serviço, nestes casos, tende a ser mais íntimo, personalizado, familiar e informal e o ritmo de jogo, mais baixo. Como podemos observar, os pagadores de banca distribuem, selectiva e discricionariamente, o seu "trabalho estético e emocional". O que determina a mobilização e aplicação destas diferentes estratégias performativas é a percepção, momentânea, do seu benefício para o profissional. Mas elas não representam duas formas de agência separadas por fronteiras claras e intransponíveis. Da 
mesma forma, elas não são homogénea e coerentemente aplicadas. Por vezes, os pagadores mobilizam as duas estratégias na mesma banca de jogo, mas em momentos diferentes. Noutras circunstâncias, aplicam-nas na mesma banca e em simultâneo, mas diferencialmente consoante os jogadores. Como tal, as ofertas estéticas e emocionais dos pagadores de banca são cuidadosamente geridas. Portanto, a sua utilização depende sempre da luta e negociação entre trabalhadores, gestores e clientes pelo controlo da interacção (MACDONALD; KORCZYNSKI, 2009). Depende da agência e do grau de autonomia dos pagadores de banca, das "estratégias de controlo" ("hegemónicas" ou "despóticas") e da activação do "panóptico" operacionalizados pelos órgãos de gestão dos casinos e, por fim, dos comportamentos dos jogadores. Ou seja, estas estratégias performativas dependem do contexto interactivo e momentâneo das bancas de jogo. As bancas, pela sua disposição espacial, pelos seus procedimentos de trabalho, pela sua dinâmica relacional, pelo seu ritmo de jogo, pelo grau de "panóptico" a que estão sujeitas, pelo encontro de determinados agentes e subjectividades e pelas possibilidades que oferecem para a acção estratégica favorecem ou limitam determinadas possibilidades de acção ${ }^{5}$. Cada banca é, portanto, um "pequeno palco" (BARNES, 2002), detentor da sua própria dinâmica de jogo e contexto interpessoal. Elas funcionam como uma espécie de "teatro" dramático (BARNES, 2002), onde se joga, não apenas dinheiro, mas, igualmente, o "carácter" (GOFFMAN, 2011), a "honra" e o "status" (GEERTZ, 1973; SALLAZ, 2008).

A "relação de serviço" implica o encontro, no mesmo espaço físico, de indivíduos que ocupam posições estruturalmente assimétricas. O cliente possui, de facto, o "direito" de consumir e de se apropriar do esforço e da atenção dos trabalhadores (SHERMAN, 2007). No entanto, estes tendem a inverter, temporária e simbolicamente, as hierarquias estabelecidas, constituindo-se como "agentes não subordinados" (SHERMAN, 2007; LAMONT, 2000; PAULES, 1991). Eles, apropriando-se dos recursos colocados à sua disposição pelo contexto jurídico, organizacional e profissional, impõem as suas próprias "hierarquias simbólicas alternativas" (LAMONT, 2000), rejeitam o carácter supostamente servil da sua actividade e conceptualizam-se como uma "força activa" (PAULES, 1991), qualificada, controladora, poderosa e superior (SHERMAN, 2007). Os pagadores, ao operacionalizarem estas duas estratégias performativas, manipulam as interacções com os clientes e com os gestores, aliando-se a uns e a outros, conforme as circunstâncias. Como referia Dino, um pagador de banca que, numa noite de trabalho, repousava na sala de convívio: "a banca é o meu palco! Aquilo que eu faço é manipulação psicológica, os clientes perdem, saem de lá a rir e ainda gratificam. Nem percebem o que lhes aconteceu". 


\section{ROLETA AMERICANA}

Em meados de Agosto de 2017, dois meses depois de ter iniciado o meu trabalho de campo, eu estava alocado ao turno da noite (21:0004:00). O concerto no primeiro piso terminara havia alguns instantes e a sala de jogos estava, particularmente, movimentada. Os jogadores aglomeravam-se em torno do bar e das bancas de jogo. O alvoroço tomava conta da sala e o clamor, formando uma totalidade ininteligível, já não permitia distinções entre slot machines, fichas, cartas, diálogos e movimentos de pessoas. Os jogadores, sentados ou em pé, perfilavam-se em redor dos $p i t s^{6}$, formando autênticas barreiras que obstaculizavam a visualização dos panos. O fumo do tabaco alastrava-se por toda a sala, ignorando as ingénuas distinções entre zona de fumadores e de não-fumadores. As barmaids, com as suas bandejas, aceleravam o passo, ziguezagueando por entre os clientes. Os seguranças, não conseguindo movimentar-se livremente pela sala, posicionavam-se estrategicamente junto aos pits, procurando um ângulo de visão privilegiado e desimpedido sobre as bancas. Eu aproveitava um esporádico momento de repouso para observar as dinâmicas de jogo na roleta americana, mas não conseguia perscrutar o seu layout.

Figura 1 - Layout da roleta americana.

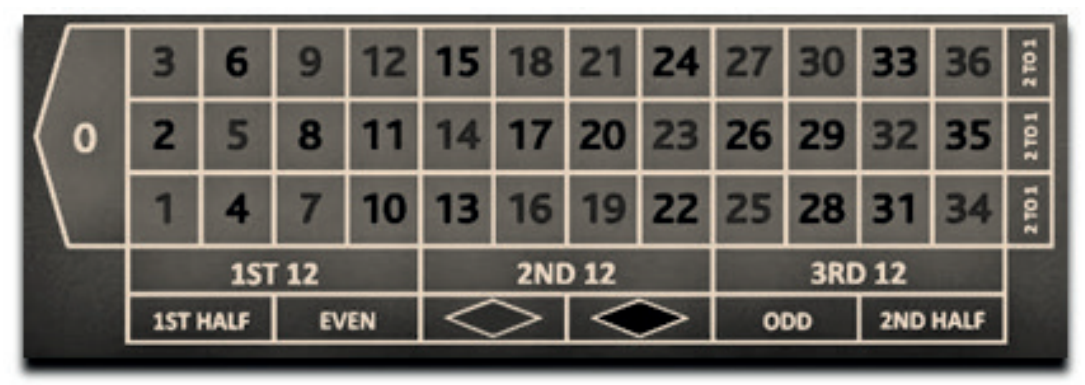

Fonte: www.google.pt.

Os jogadores cercavam as bancas, ombreando pela oportunidade de colocar as suas fichas nos panos. Alguns, mais tímidos, apostavam uma ou outra ficha nas casas exteriores: cores (encarnado ou preto); par-ímpar; dúzias (1-12, 13-24; 25-36); baixo-alto (1-18, 19-36); e colunas. Faziam a sua aposta e recuavam, aguardando o término do golpe. Outros, mais afoitos, distribuíam as suas fichas pelos seus números predilectos, saltando, numa azáfama, de roleta em roleta: “este gajo não dá nada, vou para esta". Ali chegados, repetiam a rotina anterior: fitavam, ansiosamente, o marcador digital que assinalava os resultados dos golpes precedentes e colocavam algumas fichas no layout. Apenas regressavam à banca para o apuramento do golpe, quando a bola já perdia velocidade e se precipitava sobre o prato giratório. Aproximei-me, com dificuldades, de uma roleta, procurando um ângulo de visão mais desimpedido. Atrás da banca, um jovem pagador, de expressão concentrada e movimentos céleres, isolava, com as mãos, as apostas vencedoras. De seguida, retirava as fichas perdedoras do layout. 
Figura 2 - Limpeza do pano: isolar a aposta vencedora.

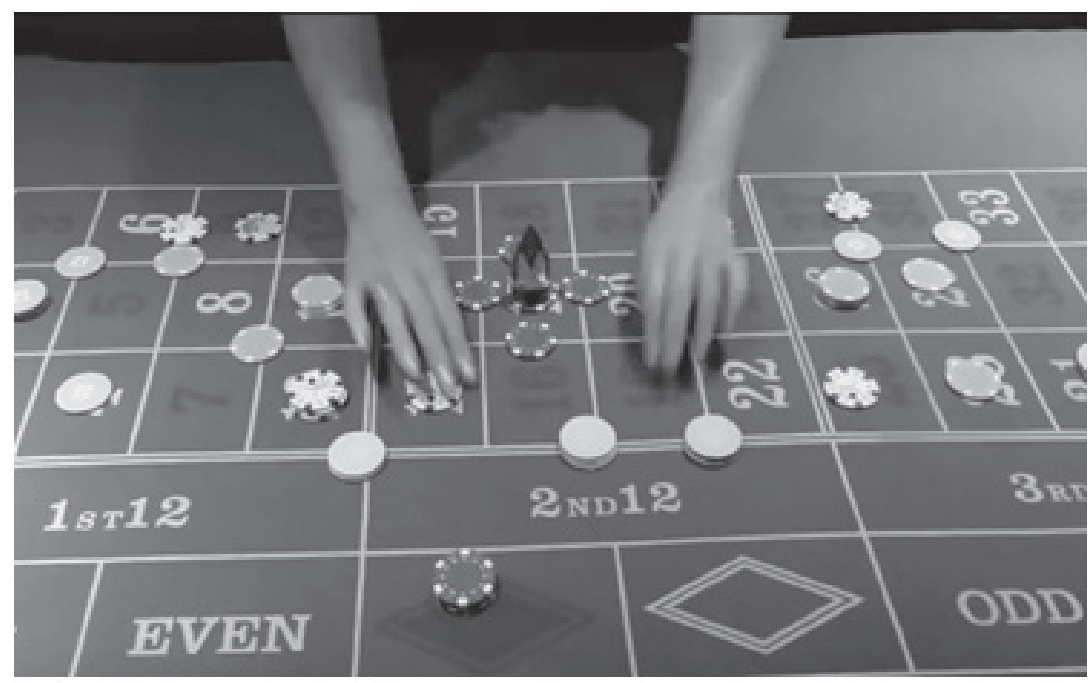

Fonte: www.youtube.pt.

Não sorria, mantinha-se silencioso e afunilava o seu olhar sobre o pano. A sua postura era formal e elegante: costas direitas, pernas ligeiramente afastadas, movimentos seguros e expressões graves. Apenas suspendia a sua visão de túnel sobre o pano quando era abordado por um jogador, momento em que respondia formal e cordialmente. No entanto, não prolongava, desnecessariamente, os diálogos, respondendo sucinta e laconicamente. Recolhidas as fichas e realizados os pagamentos, o pagador deslocava-se, lateralmente, até ao centro da mesa. Neste movimento, não se afastava um milímetro do estrado da banca e mantinham as suas mãos visíveis sobre o pano. Um cliente, forçando a sua passagem pelo aglomerado de jogadores, lançou, rispidamente, uma ficha de $500 €$ na direcção do pagador. A ficha resvalou contra o estrado da roleta, mas o cliente não ergueu o olhar para o profissional à sua frente. $\mathrm{O}$ pagador perscrutou, brevemente, os jogadores, procurando, pela trajectória da ficha, o seu proprietário. $\mathrm{O}$ jogador abriu a mão, sinalizando o valor das fichas com que pretendia jogar: $5 €$. O pagador voltou a afunilar o seu olhar sobre o pano, limpou as mãos ${ }^{7}$, pegou na ficha com a mão de fora ${ }^{8}$ e colocou-a no local de exposição dos pagamentos. De seguida, iniciou a conversão dos $500 €$ em fichas de $5 €$.

Figura 3 - Roleta americana.

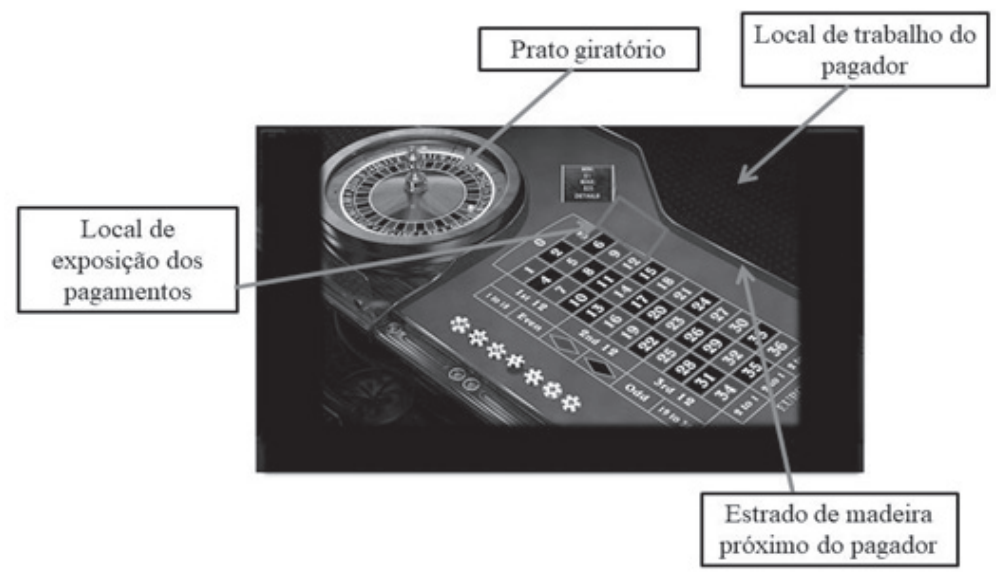

Fonte: $w w w . g o o g l e . p t$. 
Nesse instante, um novo jogador acercou-se da banca. Quando, finalmente, alcançou o pano, estendeu o braço para o pagador, mas não lhe dirigiu a palavra. Da sua mão, pendia um conjunto de notas de $20 €$. Quando percebeu a intenção do cliente, o pagador, ainda a converter o troco anterior, balançou ligeiramente a cabeça de um lado para o outro e, com o indicador, apontou para o pano. O jogador, em conversa animada com outros clientes, não se apercebeu da indicação. $O$ pagador fixou, por momentos, o olhar no cliente, mas não se intrometeu no diálogo. Aguardou, serenamente, o contacto visual. Quando, finalmente, o cliente pousou o olhar no pagador, este repetiu o gesto com o indicador, afirmando: "tem que pôr o dinheiro no pano". O jogador lançou as notas para a mesa e o pagador interrompeu a sua tarefa, limpou as mãos e colocou o conjunto de notas nas proximidades do prato giratório. De seguida, regressou à conversão do primeiro cliente. Um novo jogador, surgindo de uma roleta contígua, fitou o marcador digital, pousou a sua cerveja no estrado da roleta e atirou uma ficha de $100 €$ para o pano. Mais uma vez, o pagador interrompeu a sua tarefa e ergueu o olhar na direcção da trajectória da ficha. Quando encontrou o seu proprietário, o pagador, pacientemente, voltou a limpar as mãos e, com a mão de fora, colocou a nova ficha perto do conjunto de notas de $20 €$. Regressou, por fim, à primeira conversão, manuseando as fichas com a mão de dentro. Concluído o procedimento, o pagador voltou a limpar as mãos e, com a mão de fora, entregou as fichas ao cliente. O profissional regressou, lateralmente, ao prato giratório, limpou, novamente, as mãos e colocou, horizontal e sequencialmente, as notas de $20 €$ no local destinado à elaboração dos pagamentos. Questionou o jogador sobre o valor pretendido das fichas e executou o procedimento com celeridade e destreza. Recebendo as fichas convertidas, o cliente começou, imediatamente, a distribuí-las pelo layout. Os restantes jogadores acompanhavam-no, debruçando-se sobre a mesa e acotovelando-se para alcançar as diversas casas de aposta. Quando o pagador concluiu a conversão do último cliente, já o pano estava intensamente povoado de fichas. Estacou no centro da banca e colocou as mãos visíveis em cima do pano, aguardando que os jogadores terminassem os seus frenéticos movimentos. De cabeça mergulhada no layout, o pagador perscrutava, minuciosamente, não a cara dos jogadores, mas o movimento das suas mãos e das suas fichas. Questionou um cliente sobre a sua intenção de aposta: "isto é quadro ou cavalo?"9. Por momentos, levantou o olhar para o jogador, mas quando arrancou a resposta pretendida, inclinou novamente a cabeça sobre o pano. As fichas acumulavam-se desordenadamente nas várias casas de aposta, colorindo o pano com as suas diferentes tonalidades. Algumas formavam pequenos montes, enquanto outras se isolavam em casas menos concorridas. Os olhos do pagador percorreram, por diversas vezes, o pano de uma extremidade à outra, procurando possíveis apostas inválidas e a potencial inobservância dos máximos e mínimos 
da banca. De seguida, encaminhou-se, lateralmente, até ao prato giratório, enquanto os jogadores prosseguiam a sua indecifrável dança de mãos e de fichas. Quando alcançou o prato, o olhar do pagador abandonou, temporariamente, o pano. Com a mão de dentro, lançou a bola. Esta saiu disparada a grande velocidade, girando no sentido contrário ao do prato. O pagador retornou ao centro da mesa, endireitou as costas, colocou as mãos abertas em cima do pano e inclinou a cabeça sobre o layout. Os jogadores ainda faziam as suas apostas, precipitando-se, enérgica e urgentemente, sobre o pano. Sem desviar os olhos da banca e apenas pelo atenuar do seu rumor, o pagador apercebeu-se que a bola perdera velocidade. Nesse instante, anunciou: “jogo feito, nada mais”. Os jogadores interromperam, abruptamente, os seus movimentos e afastaram-se do layout. Este era o momento da decisão e o pagador deveria observar o pano na sua totalidade, garantindo que não se efectuavam apostas posteriores ao apuramento do resultado. O pagador observava, atentamente, as fichas nas casas de aposta e as mãos dos jogadores nas suas proximidades. A bola tombou, finalmente, sobre o prato, imobilizando-se no número 21. Os jogadores, depois do silêncio expectante que antecedeu o apuramento do golpe, exteriorizavam ostensivamente as suas emoções. Alguns, nitidamente embevecidos, vociferavam: "eu não disse que ia calhar na segunda dúzia?". Outros afastavam-se pesarosos, soltando alguns impropérios sem destinatário concreto: "foda-se, só me roubam". Nesse instante, o pagador levantou ligeiramente a cabeça para o prato e anunciou o resultado que os jogadores já conheciam: "vinte e um encarnado, twenty-one red". A sua postura e expressão facial permaneceram imperturbáveis. O pagador limpou as mãos e, com a mão de fora, colocou a dolly no número vencedor.

Figura 4 - O pagador coloca a dolly no número vencedor.

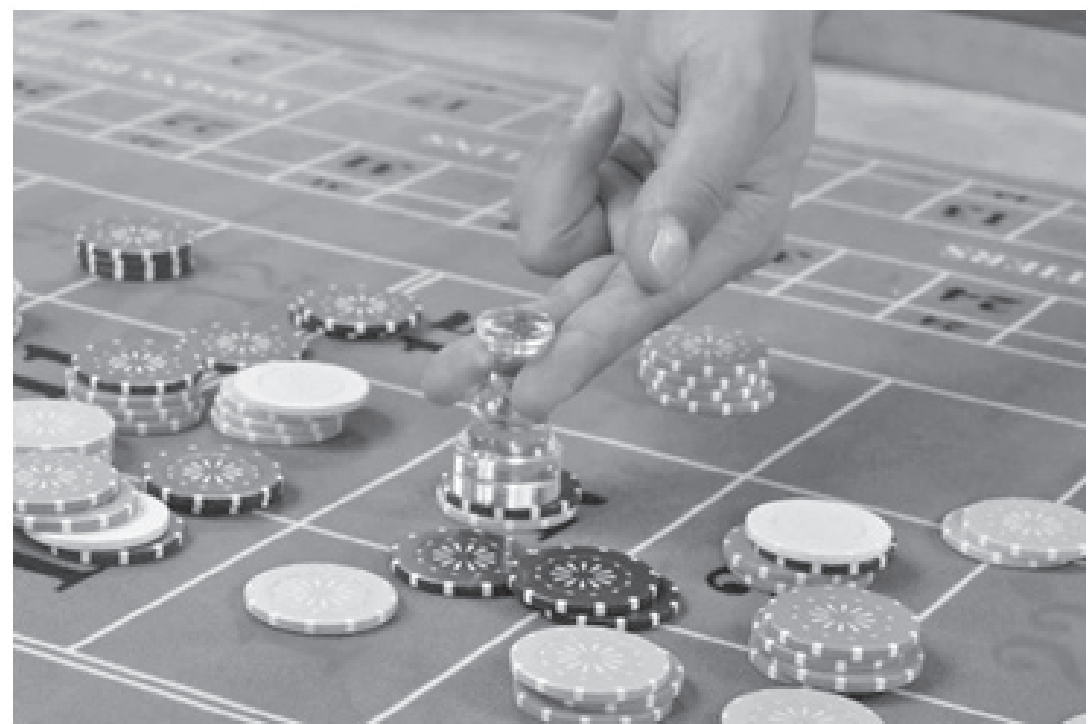

Fonte: www.google.pt.

Deslocando-se em paralelo e contra o estrado da roleta, o pagador procedeu à limpeza do layout, isolando a ficha vencedora e retirando as 
fichas perdedoras. Posteriormente, regressou ao número 21. Respeitando, rigorosamente, a ordem de pagamentos estabelecida por lei, calculou o valor de cada uma das apostas interiores.

Figura 5 - Ordem de pagamentos na roleta americana: linhas (1 e 2), ruas (3), quadros $(4,5,6$ e 7$)$, cavalos $(8,9,10$ e 11) e plenos (12).

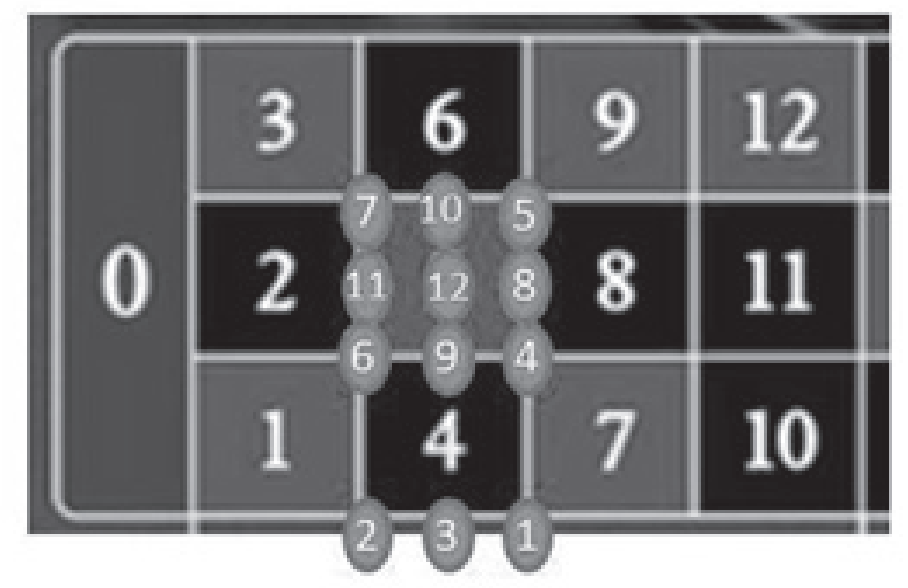

Fonte: www.google.pt.

De feições inalteráveis, o pagador não perdeu muito tempo a calcular o valor das apostas vencedoras. Apenas alguns segundos depois, começou a elaborar o primeiro pagamento, manuseando as fichas com a mão de dentro. Compôs o prémio e anunciou, em voz alta, o seu valor. O fiscal de banca, no alto da sua cadeira, acenou em concordância, autorizando o pagamento. De seguida, o pagador empurrou as fichas para o cliente. $\mathrm{O}$ jogador, recebendo o prémio, agradeceu. $\mathrm{O}$ pagador, pela primeira vez, sorriu, retornando, de imediato, ao número 21 para calcular o valor das restantes apostas.

A performance estética e emocional dos pagadores de banca numa roleta americana e, particularmente, em noites de grande movimento parecem adequar-se às afirmações de H. Lee Barnes (2002, p. 2-4): "não há um único movimento desperdiçado [...]. Se o dealer parece um robô, há uma boa razão para isso [...]. Qualquer dealer [...] admite que o seu trabalho é como um trabalho de fábrica excepto pelo elemento humano". Jeffrey Sallaz (2009, p. 29), apesar de criticar esta perspectiva, também admite: "a acção nos casinos encontra-se [...] rigidamente standardizada por procedimentos organizacionais". O atendimento do pagador parece corresponder à austeridade que o seu smoking anuncia, ajustando-se ao espaço objectivo dos casinos: à sua histórica masculinidade elitista, assente na formalidade e seriedade performativas; à sua selectividade e exclusivismo, que favorecem a manutenção da distância e da impessoalidade; à sua apertada regulamentação, que constrange os movimentos, os gestos e as palavras do pagador; e às suas "estratégias de controlo" e "regimes de produção", derivados de um "despotismo" e "panóptico", selectivamente, activados. Não obstante as ligações estruturais 
das micro-interacções, este tipo de serviço não é generalizável, porque, como mencionado anteriormente, o "trabalho estético e emocional" dos pagadores diverge consoante o contexto interactivo da banca de jogo. Desta forma, o atendimento observado em cima tende a ser performatizado no contexto específico da roleta americana. A roleta é o jogo mais popular dos casinos portugueses. Habitualmente, o seu volume e intensidade de jogo são elevados, conduzindo a uma activação mais frequente do "despotismo" e do "panóptico" organizacionais. Estas circunstâncias favorecem uma performance estética e emocional mais formal, distante e impessoal. Simultaneamente, as roletas americanas não disponibilizam lugares sentados, quer para jogadores, quer para trabalhadores. O movimento nestas bancas é ininterrupto e, frequentemente, os jogadores apostam em várias roletas em simultâneo. Por outro lado, a dimensão e complexidade do layout obrigam o pagador a concentrar-se, quase exclusivamente, sobre o pano. Ele deve estar atento: às inúmeras possibilidades de aposta (pleno, cavalo, quadro, linha, rua e apostas exteriores); às apostas inválidas; aos máximos e mínimos da banca; a actos de natureza ilícita; ao número de jogadores na mesa ${ }^{10}$; à cor e ao valor das fichas de cada jogador; e ao cálculo das apostas vencedoras. Os rígidos procedimentos de trabalho na roleta reforçam o elevado grau de disciplina e concentração a que o pagador se encontra sujeito. Ele é obrigado: a limpar as mãos sempre que manuseia valores monetários; a não se afastar do estrado da roleta; a conservar as costas direitas e as mãos visíveis sobre o pano; a realizar conversões e pagamentos com a mão de dentro; e a empurrar as fichas para o jogador com a mão de fora. Por fim, a roleta é um jogo caracterizado pelo elevado grau de aleatoriedade dos seus resultados, oferecendo poucas oportunidades para a acção estratégica. Desta forma, salvo raras excepções, o pagador e os jogadores tendem a não evidenciar a sua agência na banca e a não reivindicar o crédito pelos resultados do jogo. Por estes motivos, a roleta americana permite analisar, em maior profundidade, a performance da retirada de agência.

O contexto da roleta limita, significativamente, as micro-interacções entre trabalhadores e jogadores, evitando a personalização e favorecendo a impessoalidade, a distância, a austeridade e a formalidade relacional. No entanto, o contexto que limita as micro-interacções é, igualmente, o contexto que os trabalhadores convertem em recurso, instrumentalizando-o e manipulando-o para seu próprio benefício. A retirada de agência não é a ausência de agência, ao invés, é uma estratégia deliberadamente performatizada. Esta estratégia permite, em primeiro lugar, reduzir, substancialmente, as possibilidades de erro. Num contexto de grande mobilidade e agitação, o pagador, ao concentrar-se, exclusivamente, no pano imóvel à sua frente, descomplexifica o seu próprio trabalho. Em detrimento de uma atenção multi-focalizada, dispersa pela sala de jogos e pelos jogadores que por ela deambulam, o paga- 
dor debruça-se sobre o seu layout. A sala, neste contexto, é apenas uma imagem de fundo, desfocada e imperceptível. O pano, em contrapartida, aparece em alta definição. Todos os pormenores são observados detalhada e minuciosamente. Para fazer sentido da anarquia de movimentos e de sons, do excesso desordenado de estímulos que, permanentemente, interpelam o pagador, este operacionaliza uma atitude semelhante à do "blasé" de George Simmel (1973). Ou seja, o pagador absorve, selectivamente, esses estímulos. Absorver tudo seria comprometer o seu trabalho. Concentrar-se no pano, desconsiderando o restante movimento da sala, permite-lhe salvaguardar a sua performance laboral, isto é, o cumprimento rigoroso dos procedimentos de trabalho e das regras do jogo, o cálculo das apostas, a observância dos máximos e mínimos da banca, as apostas inválidas e os possíveis actos de natureza ilícita. Portanto, o pagador não responde a todos os estímulos da sala de jogos, mas apenas aos que à sua banca dizem respeito. Em particular, o pagador acompanha, atentamente, o movimento das fichas e das mãos dos jogadores no layout. De cabeça inclinada sobre o pano, o pagador apenas circunstancialmente levanta os olhos para os jogadores. No decorrer do jogo, as suas caras confundem-se e misturam-se. Os jogadores aparecem, maioritariamente, na sua visão periférica. Quando um jogador lança uma ficha sobre o pano, o pagador analisa a sua trajectória para descobrir o seu proprietário. É, neste momento, que o pagador perscruta o jogador e lhe associa uma cor. As fichas, com as suas diferentes tonalidades, representam os jogadores na banca. Desta forma, o jogador pode ausentar-se e movimentar-se ininterruptamente. $O$ pagador não lhe segue os passos, nem o procura pela sala. Os jogadores movimentam-se, erraticamente, pelo casino, mas as fichas apenas se deslocam, previsivelmente, sobre o pano. Desta forma, o pagador, para controlar o pano, não precisa de controlar os jogadores, mas controlar os movimentos das suas mãos e das suas fichas no layout. Mas esta performance laboral serve ainda dois outros propósitos. Em primeiro lugar, refugiando-se no cumprimento rigoroso dos procedimentos de trabalho, os pagadores neutralizam os efeitos invasivos do "panóptico" e do "despotismo" organizacionais, desresponsabilizando-se pelas ocorrências do jogo. Em segundo lugar, ao afunilar o seu olhar sobre o pano e ao focalizar a sua atenção sobre os procedimentos de trabalho, o pagador salvaguarda a sua autoridade sobre a banca de jogo. Apresentando um semblante grave e imperturbável, reduzindo os diálogos ao máximo, executando rigorosa e correctamente as suas tarefas, preservando uma atitude confiante, não hesitante e segura, o pagador sinaliza uma postura de sobriedade, profissionalismo, competência e autoridade. Controlar a banca, num contexto de grande alvoroço, não exige apenas concentração, mas a adopção de uma postura que, pela distância, impessoalidade e formalidade relacional, condicione e discipline os comportamentos dos jogadores. A adopção de uma postura que reforce, junto desses jogadores, a sua incorruptibilidade na 
banca e a impossibilidade do seu erro. Assim, os pagadores de banca, ao performatizarem esta retirada de agência, aliam-se à casa, aos seus procedimentos de trabalho e à lei de jogo, protegendo-se de eventuais erros e da imprevisibilidade dos próprios jogadores. Mas esta performance laboral permite ainda, aos pagadores, conceptualizarem-se como "agentes não subordinados", qualificados, competentes, autoritários e controladores. Permite que os pagadores convertam, temporária e simbolicamente, a sua subordinação estrutural em superioridade interactiva, configurando-se como uma "força activa" e em controlo do seu processo laboral.

Como referido anteriormente, a performance estética e emocional aqui retratada ajusta-se à roleta americana e a um elevado volume de jogo. Portanto, em noites de fraco movimento, o serviço dos pagadores de banca numa roleta americana tende a ser, substancialmente, diferente. Mas este serviço pode ainda divergir consoante as subjectividades dos agentes envolvidos (trabalhadores e jogadores). Nas mesmas circunstâncias anteriormente detalhadas, um pagador mais experiente e extrovertido certamente providenciaria um serviço mais personalizado. Da mesma forma, a presença de um jogador habitual na banca influenciaria, decisivamente, $\mathrm{o}$ atendimento do pagador. No entanto, estas formas de atendimento na roleta constituem a excepção, não a regra. Algo muito diferente acontece no blackjack.

\section{BLACKJACK}

Nos casinos, o turno da tarde (14:00-21:00) é sempre mais calmo. Num dia soalheiro de inícios de setembro, a sala de jogos estava, praticamente, vazia. No pit dos jogos carteados, estavam apenas duas bancas abertas: a do póquer e a do blackjack. Os pagadores, sentados nas suas respectivas cadeiras, conversavam descontraidamente. Ao fim de alguns minutos, aproximou-se o primeiro cliente do dia. O pagador recebeu, cordialmente, o jogador, dando-lhe as boas-vindas com um largo sorriso nos lábios. Momentos depois, sentou-se um segundo jogador na extremidade oposta da mesa. Acendeu um cigarro e expeliu o fumo na direcção do pagador. A reduzida dimensão da banca não oferece nenhuma distância de segurança. Por outro lado, pela proximidade e imobilidade dos clientes, o blackjack permite, aos trabalhadores, uma gestão diferente das suas ofertas estéticas e emocionais. O jogador, ao contrário do que sucede na roleta, não se dispersa pelo espaço. Desta forma, o pagador consegue analisar a sua fisionomia, o seu humor, as suas feições e a sua postura. Se a roleta promove a impessoalidade e a formalidade no atendimento, o afunilamento no pano e nos procedimentos de trabalho, o blackjack favorece uma maior personalização da interacção, particularmente, quando o volume de jogo é reduzido. No blackjack, os jogadores tendem a apostar valores mais baixos e a permanecer durante mais tempo na banca. Normalmente, o jogo 
decorre a um ritmo mais lento, sendo menos propenso a variações súbitas de humor. A azáfama, a agitação e o frenesim são excepcionais. Assim, as interacções são mais frequentes e a intimidade relacional maior. Isto não significa que a relação entre trabalhadores e jogadores seja, necessariamente, mais amistosa. Muito pelo contrário, é, precisamente, porque o blackjack providencia um contexto material e interactivo mais íntimo que os confrontos entre os agentes tendem a ocorrer com maior frequência. H. Lee Barnes (2002) partilha da mesma opinião:

Um jogador de blackjack pode, literalmente, empatar um dealer durante horas. [...] Aqui a interacção é mais pessoal, e normalmente o dealer é tomado como responsável pelos resultados do jogo. As confrontações são mais frequentes [...]. Normalmente, os jogadores esperam ser entretidos [...]. O ritmo do jogo e a reduzida dimensão da mesa criam uma espécie de intimidade (BARNES, 2002, p. 45).

Da mesma forma, o blackjack tende a libertar os pagadores dos rígidos procedimentos de trabalho que monopolizam a performance laboral na roleta americana. Nesta banca, o pagador controla mais facilmente o pano e o cálculo dos prémios é menos complexo ${ }^{11}$. O blackjack também permite, ao pagador, um controlo mais rigoroso do ritmo de jogo. Pertinentemente, H. Lee Barnes (2020, p. 2) assinalava a este respeito: "a arte do dealer não é a arte de Houdini, mas a arte do movimento". Novamente em oposição à roleta, a sorte e o azar no blackjack são, frequentemente, mediados por considerações estratégicas (SALLAZ, 2009). Desta forma, tanto o jogador, quanto o pagador procuram, regularmente, ostentar a sua capacidade de agência, reivindicando o crédito pelos resultados do jogo (SALLAZ, 2009).

O segundo jogador colocou uma ficha de $5 €$ na sua casa de aposta e o pagador anunciou: "jogo feito, nada mais".

\section{Figura 6 - Blackjack.}

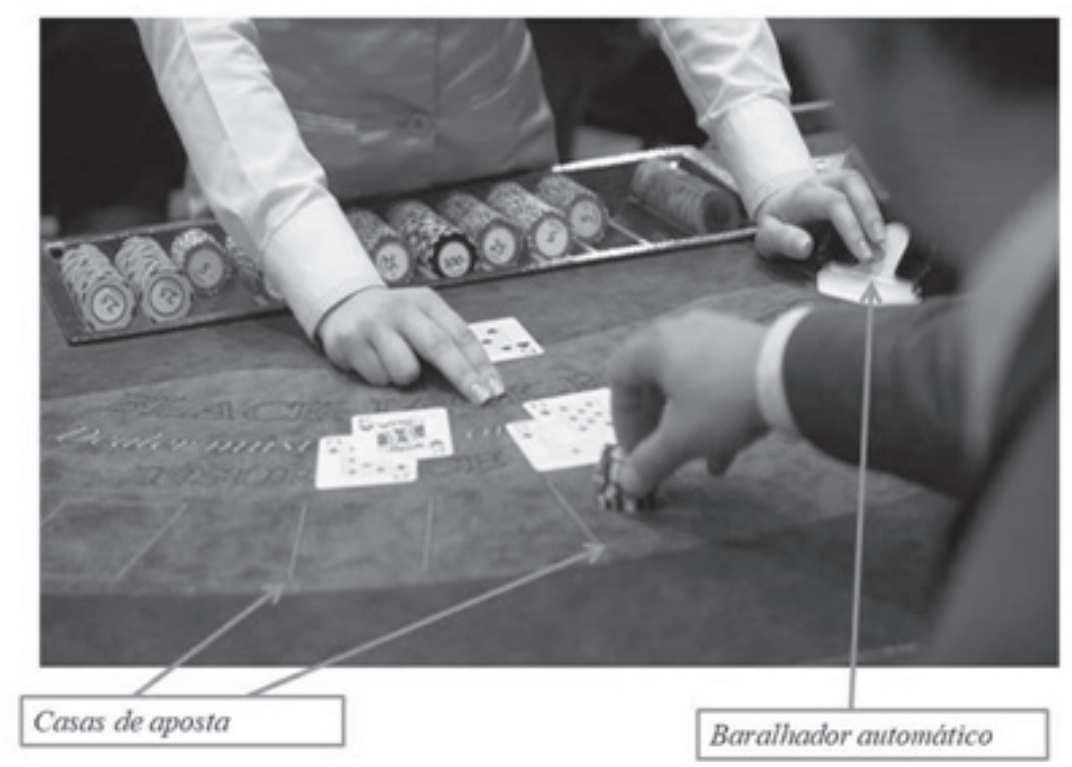

Fonte: $w w w . g o o g l e . p t$. 
De seguida, o pagador distribuiu as cartas: duas para cada jogador e duas para a casa. Finalizado o procedimento, o pagador constatou que tinha, diante de si, um rei. A segunda carta da casa estava virada para baixo, ocultando a sua face. No entanto, para os jogadores experimentados, essa carta vale sempre 10. É neste contexto que se evidenciam as possibilidades de acção estratégica no blackjack. O objectivo do jogo, tal como o nome indica, é fazer blackjack, ou seja, obter 21 com apenas duas cartas ${ }^{12}$. No entanto, nem sempre é possível alcançar este resultado. Em alternativa, os jogadores e a casa procuram aproximar-se do 21, mediante uma combinação de cartas adicionais. Se a casa ou os jogadores ultrapassarem esse valor, rebentam. Os jogadores têm a liberdade de decidir, em qualquer momento do jogo, se pretendem receber mais cartas, desistir ou ficar ${ }^{13}$. Por sua vez, o pagador, representando a casa, não toma qualquer decisão. Alcançando um valor igual ou superior a 17, a casa fica. Os jogadores ganham quando, não ultrapassando o número 21 , possuem um valor superior ao da casa. Mas porque vale sempre 10 a carta da casa que permanece oculta durante o golpe? O blackjack, nos casinos, é jogado com quatro ou seis baralhos de 52 cartas. A grandeza das cartas corresponde ao seu valor facial, mas as figuras (rei, dama e valete) valem sempre 10. Desta forma, cada baralho de blackjack é constituído por 16 cartas que equivalem a 10 ( 4 reis, 4 valetes, 4 damas e 4 10) e 4 cartas de cada restante valor ( 4 dois, 4 três, 4 cincos, etc.). Tal significa que, em cada mão, existe sempre maior probabilidade de sair uma figura (ou um 10). Por este motivo, os jogadores habituais de blackjack costumam partir do pressuposto que a carta oculta da banca vale 10. Se a casa tem, por exemplo, um 5, o jogador conclui: “15". Se a casa tem um 9, o jogador infere: “19”. Esta dedução é extremamente relevante porque, no blackjack, o jogador orienta as suas acções, não apenas de acordo com o valor das suas cartas, mas, mais importante, consoante o valor das cartas da banca. Imaginemos que o jogador tem duas cartas no valor global de 13. Habitualmente, o jogador pediria mais uma carta. No entanto, se a casa tiver, por exemplo, um 6 , o jogador especula imediatamente: "16". Tal significa que a casa é obrigada a receber mais uma carta e, nesse contexto, existem elevadas probabilidades de rebentar, porque qualquer carta de valor igual ou superior a $6(6,7,8,9,10 \mathrm{e}$ figuras) conduzem a este desfecho. Assim, mesmo que o jogador possua duas cartas de baixo valor, provavelmente, não irá pedir mais cartas. Se, pelo contrário, a casa tiver um 7 (que, para o jogador, significa “17”), o jogador dificilmente ficará satisfeito com um 13. Neste caso, ele tentará, pelo menos, alcançar o valor especulado da banca. Portanto, o blackjack é um jogo que envolve estratégia, favorecendo diferentes dinâmicas interpessoais entre pagador e jogador, nomeadamente, ao facilitar o seu mútuo investimento subjectivo no jogo.

No presente caso, no entanto, a casa possuía um rei. Ou seja, para os dois jogadores sentados à banca, a casa tinha " 20 ”. O primeiro jogador 
perscrutava, atentamente, as suas cartas: uma dama e um três (13). Por sua vez, o segundo jogador, ao observar a sua mão, soltou um longo e sonoro suspiro: um seis e um nove (15). Nenhum dos dois parecia satisfeito com o seu jogo e o primeiro jogador expressou a sua insatisfação: "começamos bem, ó amigo". O pagador sorriu empaticamente, justificando-se: "ainda agora começámos, vamos com calma". Gesticulando, o jogador pediu mais uma carta. O pagador retirou uma carta do baralhador e pousou-a em frente do cliente. A nova carta, um valete, elevou o seu total para 23: o jogador rebentou. Resignado, encolheu levemente os ombros, recostou-se na cadeira e cruzou os braços ao peito, aguardando o desfecho do golpe. Metódica e dramaticamente, o pagador contraiu as suas expressões faciais, franziu o sobrolho, comprimiu os lábios e balançou ligeiramente a cabeça de um lado para o outro, solidarizando-se com o jogador. Simultaneamente, recolheu as suas fichas e cartas, excluindo-o, formalmente, do jogo. Quando finalizou a tarefa, encolheu os ombros e ergueu as mãos para o alto, performatizando a sua impotência perante as regras do jogo e os procedimentos de trabalho. Naturalmente, esta performance contraditória, em que o pagador procura solidarizar-se com o jogador, ao mesmo tempo que cumpre, rigorosamente, os seus procedimentos de trabalho, é objecto de uma complexa gestão estética e emocional.

O pagador, ainda antes de se dirigir ao segundo jogador, vaticinou: "compenso no próximo". Desta forma, o profissional, aliando-se ao jogador contra a casa, hiperboliza a sua agência na banca, assumindo as responsabilidades pelas ocorrências do jogo. O segundo jogador, de cotovelos apoiados no pano, decide ficar. O pagador, aprovando a decisão, reiterou: "boa escolha". De seguida, o pagador revelou a carta oculta da banca: um oito. A casa possuía agora 18 e, como tal, ficava. A casa, não tendo ultrapassado o número 21 , foi quem mais dele se aproximou. Desta forma, o pagador deu o golpe por concluído, iniciando a limpeza do pano. Os jogadores estabeleceram contacto visual pela primeira vez, trocando um sorriso sarcástico. O pagador, observando o descontentamento dos jogadores, intrometeu-se: "não havia nada a fazer, se tivesse pedido carta tinha rebentado". De súbito, o pagador, procurando cooptar os jogadores à sua frente, retira a sua agência: desresponsabiliza-se das ocorrências do jogo e desculpa-se pela aleatoriedade dos resultados. Mas, logo de imediato, a situação volta a inverter-se. O primeiro jogador afirmou: "vá, agora tem que dar melhor jogo". Desembaraçadamente, o pagador retorquiu: "vamos ver o que consigo fazer". Nesse momento, enquanto distribuía as primeiras cartas dos jogadores, o pagador ergueu o olhar na minha direcção e piscou-me o olho. Distribuídas as cartas, o primeiro jogador solicitou: "mais uma". O pagador, no entanto, não retirou uma nova carta. Ao invés, questionou: “tem a certeza?". O jogador inclinou-se para a frente e fitou o pagador. Este, imperturbável, manteve a sua postura, aguardando, silenciosamente, pela resposta. O jogador 
observou novamente as suas cartas: uma figura e um 4 (14). De seguida, perscrutou o 5 da casa, afirmando: "você tem 5 , vai fazer 15 ”. O pagador contraiu os ombros e insistiu: "eu não posso dizer mais nada, mas já o estou a ajudar". Ao facultar conselhos de estratégia aos jogadores, o pagador contorna, deliberadamente, os procedimentos internos e a própria lei de jogo. O primeiro jogador, no entanto, permanecia indeciso. Nesse instante, o segundo jogador interveio: "se a banca tem 5 e você 14 , mais vale não pedir carta. A banca com 15 tem que tirar mais uma”. O pagador acenou em concordância, mas manteve-se silencioso. Finalmente, o primeiro jogador decidiu aceitar as sugestões e ficou. $\mathrm{O}$ segundo jogador, porque tinha 9, não corria o risco de rebentar. Assim, o pagador retirou uma nova carta do baralhador: um ás ${ }^{14}$. O segundo jogador, possuindo agora três cartas no valor somado de 20, optava por ficar. No entanto, o primeiro jogador não parecia satisfeito: "tirou-me o ás". O pagador interrompeu, imediatamente, o diálogo entre os jogadores: "ficava com 15 , não lhe adiantava muito".

O pagador gere o seu trabalho estético e emocional de acordo com o ambiente social na banca, ora moderando as disputas, ora aconselhando um determinado jogador, ora hiperbolizando a sua agência ("tem a certeza?"), ora retirando-a ("não lhe adiantava muito"). De seguida, o pagador revelou a carta da banca: um 10. A casa tinha agora 15 e o pagador era obrigado a retirar uma terceira carta: um 7. Perfazendo um total de 22 , a casa rebentou. Os jogadores regozijavam e o pagador, simultaneamente condescendente e conciliador, reiterava: "estão a ver? Ficou tudo bem”. De seguida, pagou os prémios dos jogadores, questionando: “então, dei um bom jogo ou não?”. O primeiro jogador, agora com um largo sorriso nos lábios, replicou: "continue assim que está a trabalhar bem". Mais uma vez, o pagador hiperboliza a sua agência na banca, reivindicando o crédito pelos resultados do jogo. Se os jogadores perdessem, o pagador, muito provavelmente, desculpar-se-ia pela aleatoriedade dos resultados, retirando a sua agência. Assim, a hiperbolização e a retirada de agência são aplicadas numa mesma banca e sobre os mesmos jogadores, de acordo com as circunstâncias imediatas.

No entanto, tal como na roleta, este trabalho estético e emocional não é passível de generalização. Aliás, o blackjack, ao favorecer a proximidade e intimidade relacional, permite observar uma maior diversidade de estratégias performativas. Nomeadamente, como vimos no exemplo em cima, a aplicação quase simultânea da hiperbolização e da retirada de agência. Mas, em determinadas circunstâncias, o atendimento dos pagadores numa banca de blackjack aproxima-se do serviço habitualmente prestado numa roleta americana. De um atendimento cordial, familiar e, por vezes, informal, o serviço dos pagadores de banca transita para a formalidade, impessoalidade e austeridade características da roleta. Esta transição ocorre, quando, por exemplo, o volume de jogo é elevado. No entanto, preservar uma postura impessoal e austera no 
blackjack não é tarefa fácil, porque esta banca coloca, à disposição dos trabalhadores, diferentes possibilidades de acção. Se a roleta, pela aleatoriedade dos seus resultados, pela distância física que estabelece entre clientes e trabalhadores e pelo movimento ininterrupto dos jogadores, permite a adopção de uma postura impessoal e autoritária, o blackjack, ao oferecer possibilidades de acção estratégica, ao fomentar a proximidade física entre clientes e trabalhadores e ao favorecer a imobilidade e a longa permanência dos jogadores, dificulta esta performance estética e emocional. Porque o blackjack promove a prestação de um serviço mais personalizado, também mais personalizados se tornam os conflitos entre trabalhadores e jogadores. Desta forma, os pagadores, quando confrontados com jogadores particularmente irascíveis, devem gerir, minuciosa e selectivamente, esses conflitos.

Dado que os conflitos entre trabalhadores e jogadores são mais frequentes no blackjack, também é nesta banca que observamos, com maior assiduidade, a estratégia performativa do dummy up and deal. Em finais de Julho de 2017, numa tranquila noite de trabalho, eu conversava descontraidamente com um colega na sala VIP. Não havia jogo nas roletas e apenas um jogador, de grande porte, se debruçava sobre o pano do blackjack. Do outro lado da banca, o pagador e o fiscal estavam tensos, os seus músculos retesados, os seus semblantes graves e os seus olhares afunilados sobre as cartas. Jogava-se pouco, mas intensamente e o silêncio na banca era ensurdecedor. Eu aproximei-me lentamente, para observar a acção de perto. O fiscal, entretanto, já havia abandonado a sua cadeira elevada, posicionando-se ao lado do pagador, atento a todos os seus movimentos. Inclinando-se para a frente, o fiscal parecia preparado para qualquer eventualidade. $\mathrm{O}$ jogador estava, nitidamente, frustrado. Apostava somas elevadas em todos os golpes e, invariavelmente, perdia. Embora não proferisse qualquer palavra, suspirava e gesticulava violentamente quando o resultado era apurado. Cerrava o punho e acometia-o contra a banca. As suas pernas, espraiadas sob a mesa, balançavam nervosamente. Não levantava os olhos do pano, apenas indicava, com as mãos, se pretendia mais cartas, ou se ficava. Nunca desistia. A cada golpe, a tensão acumulava-se, aproximando-se, vertiginosamente, de um ponto limite. O pagador, atrás da banca, suava profusamente. Estava concentrado no pano e nos procedimentos de trabalho, performatizando-os com grande celeridade. O "panóptico" e o "despotismo" estavam activados, obrigando o pagador a cumprir rigorosamente todas as prescrições legais e organizacionais. Tal como o jogador, os seus olhos não desviavam o pano e permanecia silencioso. A cada golpe, o pagador acelerava o ritmo de jogo. Distribuía as cartas e, apurado o resultado, recolhia-as sem hesitação, em gestos contínuos, fluidos e instantâneos. Ingenuamente, ao verificar que as cadeiras se encontravam desordenadas, aproximei-me da banca. Comecei pela cadeira mais distante do jogador, alinhando-a ao formato semicircular da mesa. Quando repeti o proce- 
dimento na cadeira contígua à do jogador, este, num movimento súbito e agressivo, lançou o seu punho contra o assento da cadeira. Perplexo, fitei o jogador, mas este continuava vidrado no pano. Deduzi que havia sido uma infeliz coincidência, isto é, que o jogador apenas exteriorizara a sua frustração pelo jogo no mesmo instante em que eu ajeitava a cadeira. Como tal, repeti o procedimento, mas o jogador voltou a esmurrar a cadeira, vociferando: "não mexa na puta da cadeira, a cadeira está a fazer-lhe mal? Eu quero a cadeira aqui, não volte a mexer na cadeira”. Instalou-se, imediatamente, um silêncio sepulcral na sala VIP. O chefe, a observar à distância, deu um passo em frente, mas resolveu não intervir. Os restantes pagadores, fiscais de banca e barmaids que se encontravam na sala observavam atónitos. Enquanto me afastava cautelosamente, o fiscal de banca, de olhar e semblante carregados, abanou levemente a cabeça e mexeu os lábios, murmurando: "deixa”. O chefe, à minha passagem, reconfortou-me com um ligeiro toque no ombro. O pagador, por outro lado, não esboçou qualquer reacção. Continuou a dar cartas, não desviou os olhos do pano e permaneceu imperturbável e silencioso. Esta retirada de agência, assemelhando-se ao dummy up and deal norte-americano, é performatizada quando o pagador já perdeu toda a sua autoridade na banca de jogo, quando o jogador faz uso da sua "autoridade de reserva" e quando o "despotismo" e o "panóptico" organizacionais incidem sobre ele. Através desta postura, o pagador protege-se do erro e do jogador, mas, ao contrário da retirada de agência que observámos anteriormente, não salvaguarda a sua autoridade na banca. Efectivamente, ele alia-se à casa contra o jogador, rejeita a responsabilidade pelos resultados do jogo e refugia-se nos procedimentos de trabalho. Preserva, igualmente, uma postura formal, distante e impessoal, procurando não dialogar, não sorrir, não estabelecer contacto visual e não expressar qualquer emoção ou sentimento. No entanto, neste caso, o pagador é transformado num agente subordinado, destituído de autonomia e autoridade sobre a banca de jogo. A retirada de agência, neste exemplo, é um mecanismo de defesa. Porém, o pagador ainda possuía um recurso à sua disposição: o controlo do ritmo de jogo. Sem hesitações, usava e abusava deste importante instrumento, acelerando o ritmo de jogo vertiginosamente. A cada golpe, os seus movimentos corporais, confiantes e seguros, pareciam assumir uma renovada urgência. Em menos de 30 minutos, o jogador, privado das suas fichas, abandonou a sala VIP, visivelmente irritado. Os pagadores, ao controlarem o ritmo de jogo, manipulam um recurso absolutamente fundamental no seu processo laboral, dado que ele é, particularmente, eficaz na retenção dos melhores jogadores e na expulsão dos clientes indesejáveis.

Como podemos observar, o "trabalho estético e emocional" dos pagadores de banca resiste à completa standardização e rotinização. Desta forma, na grande maioria das circunstâncias, eles substituem a sua subordinação estrutural pela superioridade interactiva. Os recursos 
colocados à sua disposição permitem-lhes gerir, estratégica e selectivamente, as suas performances laborais. Recorrendo a "hierarquias simbólicas alternativas", constituem-se como "agentes não subordinados", controladores, manipuladores, superiores, qualificados, independentes e autoritários (LAMONT, 2000; SHERMAN, 2007). Se as estruturas sociais asseguram a reprodução do seu contexto de subordinação, os trabalhadores apropriam-se e manipulam os recursos providenciados por esse contexto. A autonomia dos pagadores nas bancas de jogo nunca é, totalmente, eliminada, dado que as "estratégias de controlo" e o "regime de produção" operacionalizados pela empresa e caracterizados pela activação, selectiva do "panóptico", derivam da sua incapacidade em controlar, completamente, o seu processo laboral, os seus trabalhadores e o seu mercado de trabalho. Assim, os pagadores retêm, na maior parte das circunstâncias, a sua autonomia e independência laborais. A regulamentação do jogo, que, por um lado, constrange os movimentos e as acções dos pagadores, permite-lhes, por outro, protegerem-se do erro. Neste sentido, os pagadores conseguem aliar-se à casa, refugiando-se nos seus procedimentos de trabalho e na protecção jurídica do Estado. Por fim, os pagadores apropriam-se e instrumentalizam os recursos que o seu contexto profissional, masculinizado e elitista, lhes providencia. Como tal, os trabalhadores performatizam um serviço que não se baseia nas características da amabilidade, simpatia e deferência, mas na seriedade e formalidade interactiva. Naturalmente, estes recursos são utilizados em diferentes contextos e com diferentes objectivos. Nomeadamente, os pagadores utilizam esses recursos consoante o contexto interactivo das bancas de jogo. Assim, a significativa autonomia que os pagadores possuem no seu processo laboral permite-lhes, em determinadas circunstâncias, personalizar a relação, aliando-se ao jogador contra a casa. Constituindo-se como um "palco", detentor das suas próprias dinâmicas interpessoais, o contexto interactivo das bancas diversifica estas performances estéticas e emocionais. Os pagadores, na disputa quotidiana pelo controlo das interacções, aliando-se, instrumentalmente, à casa ou aos jogadores, atenuam o seu contexto de subordinação, mas não o subvertem. Tornam suportável a experiência da sua dominação, invertendo-a simbolicamente, mas, nesse processo, contribuem para a reprodução objectiva das assimetrias sociais.

\section{CONCLUSÃO}

Este artigo procurou analisar, etnograficamente, as micro-interacções entre pagadores de banca e jogadores num dos principais casinos portugueses. Tal como sucede na grande generalidade do sector dos serviços, a figura do cliente introduz importantes modificações no paradigma tradicional das relações laborais. Em detrimento de relações diádicas entre trabalhadores e gestores, surgem agora relações triádi- 
cas, entre trabalhadores, gestores e clientes. Se, por um lado, o cliente pode implicar uma dupla subordinação do trabalhador, por outro, a sua presença no processo laboral permite ao profissional estabelecer alianças temporárias, manipulando o seu contexto de subordinação. Apesar de hierárquica e estruturalmente subordinados a gestores e clientes, os trabalhadores instrumentalizam os recursos colocados à sua disposição para inverter, simbolicamente, as hierarquias sociais. Neste processo, os pagadores de banca utilizam duas principais estratégias performativas que consistem na distribuição selectiva do seu "trabalho estético e emocional": a retirada de agência e a hiperbolização da agência. Se a primeira permite salvaguardar a autoridade do pagador sobre a banca de jogo, aliando-se à casa contra o jogador, refugiando-se na lei de jogo, remetendo-se aos procedimentos de trabalho e preservando a impessoalidade e a formalidade no atendimento, a segunda favorece a aliança entre trabalhador e cliente, o envolvimento emocional do pagador no jogo, o incumprimento dos procedimentos laborais e a personalização da interacção. Estas estratégias performativas, apesar de conectadas às estruturas sociais que regulam a actividade profissional dos pagadores, dependem do contexto interactivo das bancas de jogo. Os pagadores instrumentalizam e manipulam o seu contexto de subordinação consoante a estratégia performativa que lhes for mais benéfica no momento. Manipulam os recursos providenciados por essas estruturas consoante os contextos interactivos e momentâneos das bancas de jogo: ora retiram agência, para preservar a sua autoridade sobre a banca quando o "panóptico" incide sobre eles; ora hiperbolizam a sua agência, para se envolverem emocionalmente no jogo quando lhes é concedida maior autonomia; ora voltam a retirar agência, para se protegerem dos erros e dos próprios jogadores. Assim, os trabalhadores constituem-se como "agentes não subordinados", controladores, independentes, autoritários e qualificados. No entanto, estas acções estratégicas, criando a dignidade na subordinação, tendem a produzir "consentimento" (BURAWOY, 1979) e não emancipação.

\section{NOTAS}

1. Por limitações de espaço, este artigo debruça-se, exclusivamente, sobre os jogos da roleta americana e do blackjack.

2. Os casinos e os interlocutores mencionados neste artigo estão protegidos pelo anonimato. Todos os nomes presentes neste texto são fictícios.

3. Todas as traduções são da exclusiva responsabilidade do autor.

4. A função de fiscal de banca consiste na supervisão e fiscalização das bancas de jogo, incluindo, do trabalho dos pagadores. É constituída por profissionais que já detêm uma significativa experiência na função de pagador.

5. A prática da gratificação também influencia, determinantemente, a performance estética e emocional do pagador. No entanto, pela especificidade da te- 
mática e por limitações de espaço, as dinâmicas relacionais envolvidas na prática da gratificação serão tratadas noutro contexto.

6. Um pit é um espaço das salas de jogos reservado, exclusivamente, à circulação dos profissionais de banca. Cada pit é composto, normalmente, por duas filas paralelas de bancas de jogo. As bancas de uma fila encontram-se de costas para as bancas da outra fila e de frente para os jogadores.

7. Este procedimento consiste em passar uma mão sobre a outra, demonstrando, às câmaras de vigilância, aos superiores hierárquicos e aos jogadores, que o pagador não subtraiu nem adicionou qualquer valor monetário ao prêmio ou aposta do jogador. O pagador deve limpar as mãos sempre que mexe em fichas ou dinheiro.

8. Na roleta, a mão de fora é a mão que se encontra mais distante do prato giratório. A mão de dentro é a que dele mais se aproxima. Dependendo da posição do prato, podem ser a esquerda ou a direita.

9. Para além das casas exteriores, a roleta americana prevê diversas possibilidades de apostas interiores: o pleno ou straight up (a aposta num único número) paga 35x o valor da aposta, o cavalo ou split (aposta em dois números) 17x, a rua ou street (aposta em 3 números) 11x, o quadro ou corner (aposta em 4 números) $8 \mathrm{x}$ e a linha ou line (aposta em 6 números) $5 \mathrm{x}$.

10. No máximo, podem estar sete jogadores a apostar nas casas interiores, não existindo limites ao número de jogadores nas casas exteriores.

11. O blackjack paga 1,5x o valor da aposta.

12. Obter o resultado de 21 com três ou mais cartas não é blackjack.

13. No blackjack, um jogador fica quando está satisfeito com a sua mão. Continua em jogo, mas não recebe mais cartas.

14. No blackjack, o ás vale 1 ou 11 consoante seja mais vantajoso para o jogador ou para a casa.

\section{REFERÊNCIAS}

ANTUNES, Ricardo. Os Sentidos do Trabalho: Ensaio Sobre a Afirmação e a Negação do Trabalho. Coimbra: Almedina, 2013.

BARNES, H. Lee. Dummy up and deal: inside the culture of casino dealing. Reno e Las Vegas: University of Nevada Press, 2002.

BURAWOY, Michael. Manufacturing consent: Changes in the labor process under monopoly capitalism. Chicago: University of Chicago Press, 1979.

BURAWOY, Michael. The politics of production: Factory regimes under capitalism and socialism. Londres: Verso Books, 1985.

CASACA, Sara Falcão. Trabalho Emocional e Trabalho Estético na Economia dos Serviços. Coimbra: Almedina, 2012.

CRESPO, Jorge. O espírito do jogo. Lisboa: Edições Colibri, 2012.

FOUCAULT, Michel. Vigiar e Punir. Petrópolis: Editora Vozes, 1999 [1975].

FRIEDMAN, Andrew. Industry and labour: Class struggle at work and monopoly capitalism. Londres: Macmillan, 1977. 
GEERTZ, Clifford. The Interpretation of Cultures. Nova Iorque: Basic Books, 1973.

GOFFMAN, Erving. Rituais de Interação: ensaios sobre o comportamento face-a-face. Rio de Janeiro: Editora Vozes, 2011 [1967].

GOMES, João. O movimento sindical nos casinos em Portugal: a Associação de Classe e o Sindicato Nacional. Ler História. No prelo.

HARVEY, D. The Condition of Postmodernity. Oxford: Basil Blackwell, 1989.

HOCHSCHILD, Arlie Russell. The Managed Hearth: commercialization of human feeling. Califórnia: University of Califórnia Press, 2003 [1979].

KEAT, Russell; WHITELEY, Nigel; ABERCROMBIE, Nicholas. The authority of the consumer. Londres: Taylor \& Francis, 1994.

LAMONT, Michèle. The Dignity of Working Men. New York: Russell Sage, 2000.

LEFEBVRE, Henri. O direito à cidade. São Paulo: Centauro Editora, 2011 [1968].

LEIDNER, Robin. Fast food, fast talk. Berkeley: University of California Press, 1993.

MACDONALD, Cameron Lynne; SIRIANNI, Carmen. Working in the service society. Filadélfia: Temple University Press, 1996.

MACDONALD, Cameron Lynne; KORCZYNSKI, Marek. Service work: critical perspectives. Nova Iorque e Londres: Routledge, 2009.

MACDONALD, Cameron Lynne; MERRILL, David. Intersectionality in the emotional proletariat: a new lens on employment discrimination in service work. In: MACDONALD, Cameron Lynne; KORCZYNSKI, Marek (Eds.). Service work: critical perspectives. Nova Iorque e Londres: Routledge, 2009.

MATOS, José Nuno. O Operário em Construção: do empregado ao precário. Lisboa: Deriva, 2015.

MILLS, Charles Wright. White Collar. Nova Iorque: Oxford University Press, 1951.

PAULES, Greta. Dishing It Out: Power and Resistance among Waitresses in a New Jersey Restaurant. Filadélfia: Temple University Press, 1991.

PORTUGAL. Ministério do Interior - Secretaria Geral. Decreto-lei no 14643 de 3 de Dezembro de 1927. Diário do Govêrno no 267, série I, 1927.

PORTUGAL. Ministério do Interior - Secretaria Geral. Decreto-lei no 41562 de 18 de Março de 1958. Diário do Governo no 56/1958, série I, 1958.

RAFAELI, Anat; SUTTON, Robert. Expressions of emotion as part of the work role. Academy of Management Review, v. 12, n. 1, p. 23-37, Janeiro, 1987.

RITZER, George. Enchanting a disenchanted world: Revolutionizing the means of consumption. Thousand Oaks, Londres, Nova Deli: Pine Forge Press, 2005. 
SALLAZ, Jeffrey. Deep plays: a comparative ethnography of gambling contests in two post-colonies. Ethnography, v. 9, n. 1, p. 5-33, mar. 2008. SALLAZ, Jeffrey. The Labor of Luck: Casino Capitalism in the United States and South Africa. Califórnia: University of Califórnia Press, 2009.

SHERMAN, Rachel. Class acts: service and inequality in luxury hotels. Berkeley, Los Angeles e Londres: University of California Press, 2007.

SIMMEL, George. A metrópole e a vida mental. In: VELHO, Otávio Guilherme (Org.). O fenómeno urbano. Rio de Janeiro: Zahar Editores, 1973 [1902].

SOLKEY, Lee. Dummy up and deal. Las Vegas: GBC Press, 1980.

VAQUINHAS, Irene Maria. Nome de código 33856: os jogos da fortuna ou azar em Portugal entre a repressão e a tolerância (de finais do século XIX a 1927). Lisboa: Livros Horizonte, 2006.

WOLKOWITZ, Carol. Bodies at Work. Londres: Sage Publications, 2006. 